\title{
PROFIL KEMAMPUAN PENALARAN MAHASISWA PGSD UNIPA SURABAYA DALAM PEMECAHAN MASALAH MATEMATIKA SEKOLAH
}

\author{
Via Yustitia \\ via.yustitia@unipasby.ac.id \\ PGSD, FKIP, Universitas PGRI Adi Buana Surabaya
}

\begin{abstract}
Abstrak. Penelitian ini bertujuan untuk mendeskripsikan kemampuan penalaran mahasiswa PGSD Universitas PGRI Adi Buana Surabaya dalam memecahkan masalah matematika sekolah. Jenis penelitian ini adalah penelitian kualitatif. Subjek yang digunakan adalah tiga orang mahasiswa yang diambil dari 38 mahasiswa, yaitu masing-masing satu mahasiswa berkemampuan matematika rendah, sedang, dan tinggi. Teknik pengumpulan data menggunakan tes tertulis dan wawancara. Analisis data dalam penelitian ini dilakukan dengan tahapan reduksi data, penyajian data, dan penarikan simpulan. Hasil penelitian ini adalah (1) subjek berkemampuan tinggi mencapai enam indikator kemampuan penalaran, yaitu menyajikan pernyataan matematika secara lisan dan tertulis, mengajukan dugaan, melakukan manipulasi matematika, memberikan alasan terhadap kebenaran solusi, memeriksa kesahihan argument, dan menarik kesimpulan atau melakukan generalisasi. (2) subjek berkemampuan sedang mencapai empat indikator kemampuan penalaran, yaitu menyajikan pernyaatan matematika secara lisan dan tertulis, mengajukan dugaan, melakukan manipulasi matematika, dan memberikan alasan terhadap kebenaran solusi. (3) subjek berkemampuan rendah dalam menyelesaikan masalah matematika sekolah belum mencapai indikator kemampuan penalaran.
\end{abstract}

Kata kunci: Kemampuan Penalaran, Matematika Sekolah, Pemecahan Masalah

\begin{abstract}
This study aims to describe the ability of PGSD students of PGRI University Adi Buana Surabaya in solving school math problems. The type of this research is qualitative research. The subjects used were three students drawn from 38 students, each of which was a student with low, medium, and high math skills. Technical data using written data and. Data analysis in this research is done with data of reduction, presentation data, and conclusion drawing. The results of this study were (1) high-ability subjects. (2) capable subjects are facing four indicators of criminal ability, namely presenting the oral and written mathematical perimadis, making suppositions, performing mathematical manipulations, and giving reasons for solutions. (3) low-ability subjects in solving school math problems have not yet reached the reasoning ability indicator.
\end{abstract}

Keywords: Ability of Reasoning, School Mathematics, Problem Solving 


\section{A. Pendahuluan}

Matematika merupakan salah pendapat Shadiq (2009) yang
satu disiplin ilmu yang dapat menyatakan bahwa materi matematika mengembangkan cara berpikir dan penalaran matematika merupakan (Hudojo). Oleh karena itu, matematika dua hal yang tidak dapat dipisahkan, diperlukan baik dalam kehidupan yaitu materi matematika dipahami sehari-hari maupun dalam menghadapi melalui penalaran dan penalaran dilatih kemajuan IPTEK sehingga perlu melalui belajar materi matematika. Jika dibekalkan kepada siswa di setiap kemampuan penalaran tidak jenjang pendidikan.

Tujuan pembelajaran matematika dikembangkan, matematika hanya akan adalah penerapan matematika dan serangkaian prosedur dan meniru keterampilan matematika, salah contoh-contoh tanpa mengetahui satunya kemampuan penalaran maknanya.

(Soedjadi, 2000). Brodie (2010) Kita dapat meningkatkan menyatakan bahwa penalaran adalah kemampuan berpikir dengan cara keterampilan dasar matematika dan memahami proses-proses yang diperlukan untuk memahami konsep- melibatkan kegiatan berpikir (Usmaedi, konsep matematika, untuk 2017). Salah satu kegiatan berpikir menggunakan ide-ide dan prosedur yang dapat melatih kemampuan matematika yang fleksibel, dan untuk penalaran adalah kegiatan memecahkan merekonstruksi pemahaman. Melalui masalah matematika. Hal tersebut penalaran, siswa dapat mengajukan sejalan dengan pendapat Gagne dalam dugaan, menyusun bukti, dan (Anni dan Rifa'i, 2009) bahwa melakukan manipulasi terhadap pemecahan masalah merupakan tipe masalah matematika sehingga dapat belajar paling tinggi yang dapat menarik kesimpulan dengan tepat. membantu dan mengembangkan

Matematika dan penalaran keterampilan intelektual tingkat tinggi, merupakan dua hal yang saling yakni penalaran matematis. Freitas berkaitan. Hal ini sejalan dengan (2008) menyatakan bahwa pemecahan JPSD Vol. 3 No. 2, September 2017 
masalah matematika tidak semata-mata bertujuan untuk mencari sebuah jawaban yang benar, tetapi menghubungkan antara apa yang mereka pelajari, kemampuan yang mereka miliki, dengan bagaimana pengetahuan tersebut akan dimanfaatkan sesuai dengan situasi.

Polya (1973) memberikan empat fase pemecahan masalah, yaitu: (1) understanding the problem (memahami masalah); (2) devising a plan (membuat rencana penyelesaian); (3) carrying out the plan (melaksanakan rencana penyelesaian) dan (4) looking back (menafsirkan kembali hasilnya). Indikator-indikator penalaran yang harus dicapai siswa untuk memecahkan masalah matematika, yaitu kemampuan menyajikan pernyataan matematika secara lisan, tertulis, gambar dan diagram; (2) kemampuan mengajukan dugaan; (3) kemampuan melakukan manipulasi matematika; (4) kemampuan menyusun bukti, memberikan alasan/bukti terhadap kebenaran solusi; (5) kemamapuan menarik kesimpulan dari pernyataan; (6) memeriksa kesahihan suatu argumen; (7) menemukan pola atau sifat dari gejala matematis untuk membuat generalisasi (Wardhani dalam Nita Putri Utami, 2014).

Kurikulum Pendidikan tinggi menjelaskan bahwa mahasiswa diharapkan tidak hanya dapat penerapan konsep saja, tetapi lebih kepada bagaimana konsep itu dapat diterapkan dalam berbagai macam situasi serta kemampuan mahasiswa dalam bernalar dan berargumentasi tentang bagaimana soal itu dapat diselesaikan. Oleh karena itu, untuk menindaklanjuti tujuan yang diharapkan, Universitas PGRI Adi Buana Surabaya sebagai lembaga pencetak tenaga kependidikan, khususnya program studi PGSD diharapkan mampu berperan serta mendukung harapan tersebut, dengan cara menyiapkan mahasiswa sebagai calon guru SD yang memiliki kemampuan penalaran dalam pemecahan masalah matematika sekolah.

Berdasarkan uraian di atas, peneliti beranggapan perlu dilakukan suatu penelitian untuk mengidentifikasi profil penalaran mahasiswa PGSD Via Yustitia 
dalam menyelesaikan masalah matematika sekolah.

\section{B. Metode Penelitian}

Jenis penelitian ini adalah kemampuan awal rendah. Teknik penelitian kualitatif. Fenomenanya pengumpulan data menggunakan tes berupa profil kemampuan penalaran tertulis dan wawancara. Instrumen mahasiswa PGSD Universitas PGRI penelitian terdiri atas instrumen utama, Adi Buana Surabaya dalam yaitu peneliti sendiri dan instrumen menyelesaikan masalah Matematika pendukung, yaitu pedoman wawancara sekolah. Penelitian ini dilaksanakan di dan tes tertulis yang berisi masalah Program Studi PGSD UNIPA Surabaya matematika sekolah.

Tahun Akademik 2016/2017.

Jenis data yang digunakan dalam Pemilihan subjek penelitian dilakukan penelitian ini adalah data kualitatif berdasarkan hasil UAS mata kuliah berupa data tentang kemampuan Konsep Matematika Lanjut. Teknik penalaran siswa yang mengacu pada yang digunakan adalah purposive enam indikator kemampuan penalaran sampling. Subjek penelitian ini adalah dalam memecahkan masalah 3 mahasiswa yang diambil dari 38 berdasarkan langkah Polya. Berikut mahasiswa 2016 A, yaitu 1 siswa indikator kemampuan penalaran kategori kemampuan awal tinggi, 1 mahasiswa dalam memecahkan siswa kategori kemampuan awal masalah matematika sekolah. sedang, dan 1 siswa kategori

Tabel 1. Indikator Kemampuan Penalaran dalam Pemecahan Masalah

\begin{tabular}{|l|l|l|}
\hline No & Tahap Pemecahan Masalah & Indikator Kemampuan Penalaran \\
\hline 1. & Memahami masalah. & $\begin{array}{l}\text { menyajikan pernyataan matematika } \\
\text { secara lisan dan tertulis. }\end{array}$ \\
\hline 2. & $\begin{array}{l}\text { Merencanakan pemecahan } \\
\text { masalah. }\end{array}$ & mengajukan dugaan \\
\hline 3. & $\begin{array}{l}\text { Melaksanakan rencana } \\
\text { pemecahan masalah }\end{array}$ & $\begin{array}{l}\text { a. melakukan } \\
\text { matematika; manipulasi } \\
\text { b. memberikan alasan terhadap } \\
\text { kebenaran solusi. }\end{array}$ \\
\hline
\end{tabular}

JPSD Vol. 3 No. 2, September 2017 


\begin{tabular}{|l|ll|lrr|}
\hline 4. & Melihat kembali & & $\begin{array}{l}\text { a. memeriksa kesahihan } \\
\text { argument; } \\
\text { b. menarik } \\
\text { membuat generalisasi. }\end{array}$ & atau \\
\hline
\end{tabular}

instrumen untuk mengetahui tingkat menggunakan triangulasi metode dan kemampuan penalaran subjek dalam dianalisis dengan melakukan reduksi memecahkan masalah matematika data, penyajian data, serta verifikasi sekolah dan dilanjutkan dengan data.

wawancara. Data yang diperoleh

\section{Hasil Penelitian dan Pembahasan}

Berdasarkan dari nilai tes UTS Adi Buana Surabaya, maka diperoleh mata kuliah Konsep Matematika subjek dalam penelitian sebagai Lanjut.dan pertimbangan dosen di berikut:

kelas 2016 A PGSD Universitas PGRI

Tabel 2. Daftar Subjek Penelitian

\begin{tabular}{|c|l|c|c|}
\hline No. & \multicolumn{1}{|c|}{ Nama } & Kelompok & Kode Subjek \\
\hline 1. & Wiwin Nur Handayani & Tinggi & S1 \\
\hline 2. & Ratih Puspita & Sedang & S2 \\
\hline 3. & Hersukma Indri Indana & Rendah & S3 \\
\hline
\end{tabular}

Pada penelitian ini digunakan Surabaya). Setiap subjek mengerjakan instrumen tes kemampuan berpikir tes kemampuan penalaran yang diberi kritis dan pedoman wawancara. symbol KP1. Untuk menguji Sebelumnya tes telah divalidasi kredibilitas data setiap subjek dalam terlebih dahulu oleh teman sejawat pemecahan masalah KP1, peneliti peneliti, yaitu Susi Hermin melakukan triangulasi waktu, yaitu Rusminati, S.Pd., M.Pd. (dosen memberikan soal setara KP1 yang PGSD Universitas PGRI Adi Buana diberi simbol KP2 pada setiap subjek Surabaya) dan Imas Srinana Wardani, di waktu yang berbeda. Hasil S.Pd., M.Pd. (dosen PGSD triangulasi menunjukkan terdapat Universitas PGRI Adi Buana konsistensi jawaban setiap subjek JPSD Vol. 3 No. 2, September 2017

Via Yustitia 
dalam menyelesaikan KP1 dan KP2 Dalam hal ini peneliti menggunakan sehingga data setiap subjek dalam data setiap subjek dalam memecahkan memecahkan KP1 dan KP2 dikatakan KP1. Berikut soal KP1 yang digunakan kredibel. Data kemampuan penalaran dalam penelitian ini dapat dilihat pada setiap subjek dapat menggunakan data tabel 3 berikut: dalam memecahkan KP1 atau KP2.

\section{Tabel 3. Soal Kemampuan Penalaran}

\begin{tabular}{|c|l|}
\hline No. & \multicolumn{1}{|c|}{ Soal } \\
\hline 1. & $\begin{array}{l}\text { Jika } 2 \mathrm{kambing} \text { Pak Danis membutuhkan 5 kg pakan rumput, maka } \\
\text { berapa kg pakan rumput yang harus disiapkan untuk 10 kambing } \\
\text { tambahan yang baru ia beli? }\end{array}$ \\
\hline 2. & $\begin{array}{l}\text { Sebuah foto berukuran 2 x 3 memiliki harga Rp 2.000,00. Jika ingin } \\
\text { memperbesar foto tersebut, konsumen dikenakan biaya Rp 2.000,00 } \\
\text { untuk setiap kelipatan ukuran 2 x 3. Berapakah biaya yang harus } \\
\text { dikeluarkan untuk memperbesar foto ukuran 3 x 4? Jelaskan. }\end{array}$ \\
\hline 3. & $\begin{array}{l}\text { Sebuah persegi panjang dan jajargenjang memiliki alas yang sama. } \\
\text { Jajar genjang dua kali lebih tinggi daripada persegi panjang. Jika } \\
\text { Anda mengetahui luas persegi panjang, apakah Anda dapat } \\
\text { mengetahui luas jajar genjang? Berapa perbandingan luas jajar } \\
\text { genjang dan persegi panjang tersebut? Jelaskan! }\end{array}$ \\
\hline
\end{tabular}

\section{Kemampuan}

Penalaran

\section{Mahasiswa Kelompok Tinggi}

Pada tahap memahami masalah, $\mathrm{S}_{1}$ mengumpulkan fakta tertulis pada soal dengan cara menyebutkan hal-hal yang diketahui dan ditanyakan. $\mathrm{S}_{1}$ dapat memahami masalah pada soal dengan baik. $\mathrm{S}_{1}$ menuliskan dengan benar apa yang diketahui dan ditanya pada soal. Pada soal nomor $1, \mathrm{~S}_{1}$ menerjemahkan permasalahan matematika sekolah dengan simbol matematika. Pada soal nomor $2 \mathrm{~S} 1$ mengomunikasikan permasalahan JPSD Vol. 3 No. 2, September 2017 melalui sketsa gambar. Berdasarkan hasil wawancara dengan $S_{1}$ mampu menjelaskan secara lisan arti dari simbol matematika yang digunakan dengan benar. $S_{1}$ harus dua kali membaca soal untuk bisa memahami soal dengan baik sehingga melajutkan perencanaan penyelesaian masalah.

Pada tahap merencanakan penyelesaian masalah, $S_{1}$ dapat cepat mengambil sebuah keputusan tentang strategi yang akan digunakan untuk menyelesaikan masalah tersebut. $\mathrm{S}_{1}$ menjelaskan secara jelas hubungan Via Yustitia 
dari masalah yang diberikan. Soal nomor 1 akan diselesaikan menggunakan konsep perbandingan senilai dan soal nomor 2 menggunakan konsep perbandingan dan geometri. Berdasarkan hasil wawancara peneliti dengan $\mathrm{S}_{1}$ menunjukkan $\mathrm{S}_{1}$ merencanakan penyelesaiannya denga satu strategi, serta mampu menjelaskan secara lisan strategi yang akan digunakan. $\mathrm{S}_{1}$ mampu menjelaskan dengan baik alasan penggunaan konsep perbandingan senilai untuk menyelesaikan soal nomor 1. Semakin banyak jumlah kambing semakin banyak pula makanan yang harus disediakan. $\mathrm{S}_{1}$ juga mampu menjelaskan dengan baik alasan penggunaan konsep perbandingan dan geometri untuk menyelesaikan soal nomor 2. Konsep perbandingan digunakan untuk membandingkan luas dua bangun datar yang diminta pada soal dan konsep geometri (luas bangun datar) digunakan untuk menyelesaikan permasalahan perhitungan pada soal.

Pada tahap pelaksanaan rencana, $\mathrm{S}_{1}$ menyelesaikan masalah soal sesuai rencana sebelumnya sehingga melakukan perhitungan dengan benar. $\mathrm{S}_{1}$ sudah mampu melakukan manipulasi matematika sesuai dengan rencana. $S_{1}$ sudah mampu memberikan alasan terhadap kebenaran solusi.

Pada tahap melihat kembali, $\mathrm{S}_{1}$ mampu menuliskan kesimpulan dari penyelesaian masalah tersebut dengan tepat. S1 mengecek kembali penyelesaian yang diperoleh sebelumnya dan mengaitkan dengan konteks masalah yang diberikan pada soal. $\mathrm{S}_{1}$ memberikan keyakinan atas jawaban yang diperoleh dengan membaca kembali apa yang ditanyakan.

Mahasiswa berkemampuan tinggi mampu menyelesaikkan masalah matematika sekolah dengan menggunakan kemampuan penalarannya dengan baik. Dari awal tahap memahami masalah sampai dengan melihat kembali atau membuat sebuah kesimpulan. Hal ini sejalan dengan pendapat Lithner (2008), penalaran adalah pemikiran yang diadopsi untuk menghasilkan pernyataan dan mencapai kesimpulan pada pemecahan masalah yang tidak Via Yustitia 
selalu didasarkan pada logika formal sehingga tidak terbatas pada bukti.

\section{Kemampuan Penalaran}

\section{Mahasiswa Kelompok Sedang}

Pada tahap memahami masalah, $\mathrm{S}_{2}$ mampu memahami masalah, hal ini dapat dilihat dari hasil tes. $\mathrm{S}_{2}$ sudah menuliskan apa yang diketahui dan $\begin{array}{llll}\text { ditanyakan pada soal. } & \mathrm{S}_{2}\end{array}$ menerjemahkan permasalahan matematika sekolah dengan bahasanya sendiri. Pada soal nomor 2 S1 mengomunikasikan permasalahan dengan bahasanya sendiri dan dilengkapi dengan gambar. Berdasarkan hasil wawancara dengan $\mathrm{S}_{2}$ mampu menjelaskan permasalahan dalam soal secara lisan. $\mathrm{S}_{2}$ harus membaca soal berulang-ulang untuk bisa memahami soal dengan baik. Membutuhkan waktu berpikir lebih untuk dapat merencanakan penyelesaian masalah.

Pada tahap merencanakan penyelesaian masalah, $\mathrm{S}_{2}$ kurang cepat dalam mengambil sebuah keputusan tentang strategi yang akan digunakan untuk menyelesaikan masalah. S1 menjelaskan secara jelas hubungan dari masalah yang diberikan. Soal JPSD Vol. 3 No. 2, September 2017 nomor 1 akan diselesaikan menggunakan konsep perbandingan senilai dan soal nomor 2 menggunakan konsep perbandingan dan geometri. Berdasarkan hasil wawancara peneliti dengan S1 menunjukkan S1 merencanakan penyelesaiannya denga satu strategi, serta mampu menjelaskan secara lisan strategi yang akan digunakan. S1 mampu menjelaskan dengan baik alasan penggunaan konsep perbandingan senilai untuk menyelesaikan soal nomor 1. Semakin banyak jumlah kambing semakin banyak pula makanan yang harus disediakan. S1 juga mampu menjelaskan dengan baik alasan penggunaan konsep perbandingan dan geometri untuk menyelesaikan soal nomor 2. Konsep perbandingan digunakan untuk membandingkan luas dua bangun datar yang diminta pada soal dan konsep geometri (luas bangun datar) digunakan untuk menyelesaikan permasalahan perhitungan pada soal. $\mathrm{S}_{2}$ sudah mampu mengajukan dugaan terkait masalah pada soal.

Pada tahap pelaksanaan rencana, S1 menyelesaikan masalah soal sesuai Via Yustitia 
rencana sebelumnya sehingga melakukan perhitungan dengan benar. $\mathrm{S}_{1}$ sudah mampu melakukan manipulasi matematika sesuai dengan rencana. $S_{1}$ sudah mampu memberikan alasan terhadap kebenaran solusi. Hal ini sejalan dengan hasil penelitian Mahendra (2015), siswa dengan kategori kemampuan awal sedang memiliki kecenderungan menggunakan unsur-unsur penalaran induktif dan deduktif dengan cukup baik.

Pada tahap melihat kembali, $\mathrm{S}_{1}$ belum mampu menuliskan kesimpulan dari penyelesaian masalah tersebut dengan tepat. $S_{1}$ tidak mengecek kembali penyelesaian yang diperoleh sebelumnya dan mengaitkan dengan konteks masalah yang diberikan pada soal. $\mathrm{S}_{1}$ tidak memberikan keyakinan atas jawaban yang diperoleh dengan membaca kembali apa yang ditanyakan. Penalaran matematika tidak hanya kemampuan berhitung dan analisis, melainkan juga mencakup beberapa proses, antara lain: mengumpulkan bukti, menganalisis data, membuat dugaan, membangun argumen, menarik simpulan, JPSD Vol. 3 No. 2, September 2017 mensahihkan simpulan yang logis, serta membuktikan kebenaran pernyataan dengan tegas (English, 2010).

\section{Kemampuan}

Penalaran

\section{Mahasiswa Kelompok Rendah}

Pada tahap memahami masalah, $\mathrm{S}_{3}$ belum dapat menyajikan pernyataan matematika secara tertulis. Pada soal nomor $1, \mathrm{~S}_{3}$ menuliskan kembali kalimat pada soal, namun tidak menuliskan apa yang ditanyakan. Pada soal nomor $2, \mathrm{~S}_{3}$ tidak menuliskan apa yang diketahui dan ditanyakan pada soal. Berdasarkan hasil wawancara, $\mathrm{S}_{3}$ kesulitan dalam memahami soal dengan baik. Sudah membaca berulang-ulang soal tersebut namun ia tidak dapat memahami permasalahan pada soal. Hasil wawancara menunjukkan bahwa $S_{3}$ tidak mampu menjelaskan secara lisan apa yang diketahui, ia tidak memahami apa yang ditanyakan pada soal sehingga ia tidak mampu membuat strategi untuk menyelesaikan masalah tersebut.

Berdasarkan hasil penelitian diperoleh bahwa subjek berkemampuan rendah belum mencapai satu pun indikator Via Yustitia 
kemampuan penalaran. Mahasiswa dimiliki mahasiwa sebelumnya belum sudah memahami konsep dasar mampu dikoneksikan untuk matematika yang sudah dibahas pada mengembangkan pengetahuan mata kuliah Konsep Matematika selanjutnya. Menurut Adegoke (2013), Dasar, namun mahasiswa belum dosen matematika perlu melakukan mampu menghubungkan materi yang program khusus untuk membantu siswa dipelajari untuk menyelesaikan mengembangkan dan meningkatkan matematika sekolah. Hal ini sejalan kemampuan penalaran matematis dengan hasil penelitian Hapsari mereka dan pada akhirnya (2016), kemampuan pemecahan meningkatkan pencapaian mereka masalah bagi mahasiswa dengan dalam matematika. Menurut Voss et al. penalaran rendah tidak dapat (Lak Cho et, al., 2002), problem solver menentukan syarat cukup dan syarat membutuhkan argumentasi logis untuk perlu dalam memahami masalah dan mengembangkan dan menentukan tidak dapat menyelesaikan masalah suatu solusi terpilih, menghasilkan dengan langkah yang benar.

Menurut Sanapiah (2014), mendukung solusi dengan data dan kemampuan penalaran yang sudah fakta.

\section{Simpulan}

Berdasarkan hasil penelitian dan empat indikator kemampuan penalaran, pembahasan dapat disimpulkan profil yaitu menyajikan pernyaatan kemampuan penalaran mahasiswa matematika secara lisan dan tertulis, PGSD Universitas pgri Adi Buana mengajukan dugaan, melakukan Surabaya dalam memecahkan masalah manipulasi matematika, dan matematika sekolah sebagai berikut: memberikan alasan terhadap kebenaran (1) subjek berkemampuan rendah solusi. (3) subjek berkemampuan tinggi belum mencapai satupun indikator mencapai enam indikator kemampuan kemampuan penalaran. (2) subjek penalaran, yaitu menyajikan pernyataan berkemampuan sedang mencapai matematika secara lisan dan tertulis, JPSD Vol. 3 No. 2, September 2017 
mengajukan dugaan, melakukan soal penalaran sehingga mahasiswa manipulasi matematika, memberikan terbiasa memecahkan masalah alasan terhadap kebenaran solusi, matematika sekolah. Dosen juga harus memeriksa kesahihan argumen, dan memperhatikan perbedaan kemampuan menarik kesimpulan atau melakukan mahasiswa. Perlu diadakan penelitian generalisasi.

Hendaknya dosen memilih model selanjutnya terkait faktor-faktor yang menyebabkan kesulitan mahasiswa pembelajaran yang tepat untuk berkemampuan rendah untuk meningkatkan kemampuan penalaran menyelesaikan masalah matematika mahasiswa. Dosen juga harus sekolah. membiasakan memberikan latihan soal-

\section{Daftar Pustaka}

Adegoke, B.A. 2013. Modelling the Relationship between Mathematical Reasoning Ability and Mathematics Attainment. Journal of Education and Practice, 3 (17), 54-61.

Anni, T.C., dan Rifa'i, A. 2009. Psikologi Pendidikan. Semarang: UNNES Press.

Brodie, K. 2010. Teaching mathematical reasoning in secondary school classrooms. New York: Springer Publisher.

English, L. D. 2004. Mathematical and analogical reasoning of young learners. London: Lawrence Erlbaum Associates Publishers.

Freitas, D.E. 2008. Critical Mathematics Education: Recognizing the Ethical

JPSD Vol. 3 No. 2, September 2017
Dimension of Problem Solving. International Electronic Journal of Mathematics Education, 3 (2), 79-95.

Hapsari, J. 2016. Analisis Kemampuan

Penalaran Matematika

Berdasarkan Langkah-Langkah

Polya untuk Memecahkan

Masalah Materi Bangun Datar pada Mahasiswa PGSD

Universitas Slamet Riyadi.

Jurnal Eks, 11 (1), 1-8.

Hudojo, H. 2003. Pengembangan Kurikulum dan Pembelajaran Matematika. Malang: Universitas Negeri Malang.

Lithner, J. 2008. A Research Framework for Creative and Imitative Reasoning. Education Study Mathematic, 6 (67), 255276.

Lak Cho, K., \& Jonassen, D. H. (2002). The Effects of Argumentation Schaffolds on Argumentation and

Via Yustitia 
Problem Solving. ETR\&D, 50(3), 5-22.

Mahendra, R., Murtafiah, W., \& Adamura, F. 2013. Profil Penalaran Siswa Kelas X SMA dalam Menyelesaikan Masalah Persamaan

Kuadrat Ditinjau dari Kemampuan Awal Siswa. Jurnal Ilmiah Pendidikan Matematika, 4 (1), 1-9.

Nur, S.A. \& Rahman, A. 2013.

Pemecahan Masalah

Matematika sebagai Sarana Mengembangkan Penalaran Formal Siswa Sekolah

Menengah Pertama. Jurnal Sainsmat, 2 (1), 84-92.
Sanapiah. 2014. Analisis Penalaran Mahasiswa Calon Guru dalam Pemecahan Masalah Matematika Sekolah. Jurnal Kependidikan, 13 (4), 421-426.

Shadiq, F. 2009. Kemahiran Matematika. Yogyakarta: Depdiknas.

Soedjadi, R. 2000. Kiat Pendidikan Matematika di Indonesia. Jakarta: Direktorat Pendidikan Tinggi, Departemen Pendidikan Nasional.

Usmaedi. 2017. Menggagas Pembelajaran HOTS pada Anak Usia Sekolah Dasar. JPSD, 3 (1), 82-95. 